\title{
Penerapan Model Pembelajaran Inquiry untuk Meningkatkan Hasil Belajar Siswa pada Pelajaran Geografi dengan Materi Pokok Dinamika Kependudukan di Indonesia Kelas XI SMAN 10 Kota Jambi
}

\author{
Ermiwati \\ SMAN 10 Kota Jambi \\ Correspondence email: ermiw72@gmail.com
}

\begin{abstract}
This research aims to determine the effectiveness of student learning outcomes in Geography subjects with the subject of Population Dynamics in Indonesia class XI IPS 1 SMAN 10 Jambi using inquiry learning model. Population and samples in this study were students of class XI IPS 1, amounting to 30 students. The data obtained based on this study Based on the results obtained in the above study between the two cycles it can be obtained data that in cycle 1 the average value of student learning activities in first cycle was 2.6 while the average value in second cycle was obtained. amounted to 3,4. This shows that there is an increase in student learning activities. Based on the results obtained in the above research, between the two cycles, it can be obtained data that in first cycle the average value of teacher activity was 3.4, and the average value insecond cycle was 3.5. This shows that there is an increase in teacher activity. Based on the results obtained in the above research, especially on the subject of Population Dynamics in Indonesia, there are significant results on student learning completeness in first cycle and second cycle was $10 \%$.
\end{abstract}

Keywords: inquiry; learning outcomes; Geography

\section{PENDAHULUAN}

Pendidikan merupakan komponen penting dalam kehidupan. Pendidikan merupaka hal yang bersifat universal yang berlaku dimana saja, kapan saja dan siapa saja untuk mendapakan ilmu pengetahuan. Pendidikan selalu mengalami perubahan, perkembangan dan perbaikan sesuai dengan perkembangan di segala kehidupan. Perubahan dan perbaikan dalam bidang pendidikan melip uti berbagai komponen yang terlibat di dalamnya baik itu pelaksana pendidikan di lapangan yang meliputi kompetensi guru dan kualitas tenaga pendidik. Pendidikan dan mutu menejemen pendidikan termasuk perubahan dalam metode dan strategi pembelajaran yang lebih inovatif. Upaya perubahan dan perbaikan tersebut bertujuan membawa kualitas pendidikan Indonesia lebih baik. Dalam rangka men cerdaskan kehidup an ban gsa, maka peningk atan mutu pendidikan suatu hal yang sangat penting bagi pemban gun an berkelanjutan di segala aspek kehidupan manusia. Sistem pendidikan nasional senantiasa harus dikemban gkan sesuai dengan kebutuhan dan perkembangan yang terjadi baik di tingkat lokal, nasional, maupun global (Mulyasa : 2006:).

Pendidikan yang baik akan menghasilkan kualitas output yang baik pula. Kualitas output dapat dilihat dari hasil pembelajaran yang diperoleh leh siswa. Hasil belajar merupakan proses untuk menentukan nilai belajar siswa melalui kegiatan penilaian atau pengukuran hasil belajar. Berdasarkan pengertian di atas hasil belajar dapat menerangai tujuan utamanya adalah untuk mengetahui tingkat keberhasilan yang dicapai oleh siswa setelah mengikuti suatu kegiatan pembelajaran, dimana tingkat keberhasilan tersebut kemudian ditandai dengan skala nilai berupa huruf atau kata atau simbol ataupun lambang.

Hasil belajar menunjukkan kemampuan siswa yang sebenarnya yang telah mengalami proses pengalihan ilmu pengetahuan dari seseorang yang dapat dikatakan dewasa atau memiliki pengetahuan kurang. Jadi dengan adanya hasil belajar, orang dapat mengetahui seberapa jauh siswa dapat menangkap, memahami, memiliki materi pelajaran tertentu. Atas dasar itu pendidik dapat menentukan strategi belajar mengajar yang lebih baik.

Berdasarkan Peraturan pemerintah Republik Indonesia nomor 19 tahun 2005 tentang standar nasional pendidikan, memuat tentang standar proses, dinyatakan bahwa proses pembelajaran pada satuan pendidikan diselenggarakan secara interaktif, inspiratif, menyenangkan, menantang, memotivasi peserta didik untuk berpartisipasi aktif, serta memberikan ruang yang cukup bagi prakarsa, kreativitas dan kemandirian sesuai dengan bakat, minat dan perkembangan fisik serta psikologis peserta didik. Dari rumusan tersebut mengisyaratkan bahwa siswa bukan hanya memahami materi pelajaran untuk mengembangkan kemampuan intelektual saja, melainkan bagaimana pengetahuan itu dipahaminya dapat mewarnai perilaku yang ditampilkan dalam kehidupan nyata. Tujuan pengajaran yang dilaksanakan di dalam kelas menurut Mager adalah menitik beratkan pada perilaku siswa atau perbuatan (performance) sebagai suatu jenis out put yang terdapat pada siswa dan teramati serta menunjukkan bahwa siswa tersebut telah melaksanakan kegiatan belajar (Martinis Yamin, 2005:).

Secara umum, inkuiri merupakan proses yang bervariasi dan meliputi kegiatan-kegiatan mengobservasi, merumuskan pertanyaan yang relevan, mengevaluasi buku dan sumber-sumber informasi lain secara kritis, 
merncanakan penyelidikan atau investigasi, me-review apa yang telah diketahui, melaksanakan percobaan atau eksperimen dengan menggunakan alat untuk memperoleh data, menganalisis dan menginterpretasi data, serta membuat prediksi dan mengkomunikasikan hasilnya (Susanto : 2013). Tujuan utama pembelajaran berbasis inkuiri menurut National Research Council dalam (Susanto : 2013), sebagai berikut :

1. Mengembangkan keinginan dan motivasi siswa untuk mempelajari prinsip dan konsep sains.

2. Mengembangkan keterampilan ilmiah siswa sehingga mampu bekerja seperti layaknya seorang ilmuan.

3. Membiasakan siswa bekerja keras untuk memperoleh pengetahuan.

Selanjutnya Susanto (2013:174) menyatakan bahwa pembelajaran inkuiri yang mensyaratkan keterlibatan siswa aktif terbukti dapat meningkatkan hasil belajar dan sikap anak terhadap lingkungan sekitar. Ada beberapa hal yang menjadi ciri utama strategi pembelajaran inkuiri menurut Hamruni (2012:89). Pertama, strategi inkuiri menekankan kepada aktivitas siswa secara maksimal untuk mencari dan menemukan. Kedua, seluruh aktivitas siswa yang dilakukan siswa diarahkan untuk mencari dan menemukan jawaban sendiri dari sesuatu yang dipertanyakan, sehingga diharapkan dapat menumbuhkan sikap perca diri (Mardapi Djemari: 2012). Ketiga, tujuan penggunaan strategi pembelajaran inkuiri adalah mengembangkan kemampuan berpikir secara sistematis, logis, dan kritis, atau mengembangkan kemampuan intelektual sebagai bagian dari proses mental.

Berdasarkan penjabaran di atas penulis menemukan metode yang tepat untuk meningkatkan hasil belajar siswa yaitu dengan menggunakan model pembelajaran inkuiri. Model mempelajaran inkuiri dirasa sangat tepat dengan materi Dinamika Kependudukan di Indonesia karena dengan model pembelajaran tersebut siswa dapat mencari serta menemukan permasaahan yang ada di setiap perubahan kependudukan yang ada di Indonesia.

\section{METODE}

Penelitian ini dilaksanakan pada siswa kelas IX IPS tahun ajaran 2017/2018 di SMA Negeri 10 Kota Jambi dengan jumah siswa 30 orng. Penelitian ini dilaksanakan denngan menggunakan dua siklus yaitu siklus 1 atau siklus 2. Setiap siklus ini dilaksanakan sesuai dengan perubahan yang ingin dicapai. Berdasarkan observasi awal dan diskusi dengan guru bidang studi geografi, ditetapkan bahwa tindakan yang digunakan untuk meningkatkan hasil belajar georafi khusunya pada materi pokok pemanfaatan dan pelestarian lingkungan hidup adalah memberikan pelajaran dengan menggunakan model pembelajaran kooperatif. Prosedur penelitian ini dilaksanakan sebanyak dua siklus yang terdiri dari perencanaan, tindakan, pengamatan, dan refleksi. (Suharsimi Arikunto : 2013)

\section{HASIL DAN PEMBAHASAN \\ Siklus 1}

Data yang diperoleh dalam aktivitas belajar siswa berdasaran siklus 1 antara lain dapat dilihat pada halaman berikutnya :

\begin{tabular}{clc}
\hline NO & \multicolumn{1}{c}{ Jenis Kegiatan } & Jumlah \\
\hline 1 & Siswa mendengarkan dan memperhatikan guru & $2,5 \%$ \\
2 & Siswa membaca buku dan LKS & $2,7 \%$ \\
3 & Siswa mampu mengungkapkan pemikiran tentang materi yang diajarkan & $2,7 \%$ \\
4 & Siswa berdiskusi dalam kelompok belajar & $2,7 \%$ \\
5 & Siswa mengajukan dan menanggapi pertanyaan & $2,7 \%$ \\
6 & Siswa menghargai pendapat orang lain & $2,5 \%$ \\
7 & Siswa mempresentasikan hasil kerja kelompoknya di depan kelas & $2,6 \%$ \\
\hline
\end{tabular}

Bedasarkan data yang diperoleh dalam aktivitas belajar siswa dapat diperoleh kesimpulan bahwa siswa yang mendengarkan dan memperhatika guru sebanyak 2,5\%. Siswa yang membaca buku dan LKS sebanyak 2,7\%. Siswa mampu mengungkapkan pemikiran tentang materi yang diajarkan sebnayak $2,7 \%$. Siswa berdiskusi dalam kelompok belajar sebanyak $2,7 \%$. Siswa mengajukan dan menanggapi pertanyaan sebanyak $2,7 \%$. Siswa menghargai pendapat orang lain sebanyak 2,5\% dan siswa mempresentasikan hasil kerja kelompoknya di depan kelas sebanyak 2,6\%.

Berdasarkan data yang diperoleh pada siklus 1 pada aktivitas guru antara lain :

\begin{tabular}{clc}
\hline NO & \multicolumn{1}{c}{ Jenis Kegiatan } & Jumlah \\
\hline 1 & Guru memberi salam dan menyapa siswa & $3 \%$ \\
2 & Guru mengecek kehadiran siswa & $3 \%$ \\
3 & Guru memberi motivasi & $2 \%$ \\
4 & Guru menyampaikan tujuan pembelajaran & $3 \%$ \\
5 & Guru menyampaikan metode pembelajaran & $3,5 \%$ \\
6 & Guru menjelaskan materi pembelajaran & $3 \%$
\end{tabular}


Ermiwati, Penerapan Model Pembelajaran Inquiry untuk Meningkatkan Hasil Belajar Siswa pada Pelajaran Geografi dengan Materi Pokok Dinamika Kependudukan di Indonesia Kelas XI SMAN 10 Kota Jambi

7 Guru mengajukan pertanyaan

8 Guru menginstrusikan siswa untuk berdiskusi

9 Guru menginstruksikan siswa untuk bekerja sama

10 Guru menugaskan siswa untuk memberi komentar

11 Guru merefleksi tugas siswa

12 Guru membimbing siswa untuk menarik kesimpulan

13 Guru memberikan tugas untuk di rumah
$2 \%$
$3 \%$
$2,5 \%$
$2 \%$
$2,5 \%$
$2,5 \%$
$3 \%$

Berdasarkan analisis data yang diperoleh didapat data guru memberi salam dan menyapa siswa sebanyak $3 \%$. Guru mengecek kehadiran siswa sebanyak 3\%. Guru memberi motivasi sebanyak 2\%. Guru menyampaikan tujuan pembelajaran sebanyak $3 \%$. Guru menyampaikan metode pembelajaran sebanyak 3,5\%. Guru menjelaskan materi pembelajaran sebanyak $3 \%$. Guru mengajukan pertanyaan sebanyak $2 \%$. Guru menginstrusikan siswa untuk berdiskusi sebanyak $3 \%$. Guru menginstruksikan siswa untuk bekerja sama sebanyak 2,5\%. Guru menugaskan siswa untuk memberi komentar sebanyak $2 \%$. Guru merefleksi tugas siswa sebanyak 2,5 \%. Guru membimbing siswa untuk menarik kesimpulan sebanyak 2,5\% dan Guru memberikan tugas untuk di rumah sebanyak 3\%.

\section{Data Hasil Belajar Siswa Pada Siklus 1}

Data hasil belajar siswa pada siklus 1 pada materi pokok dinamika kependudukan di Indonesia diperoleh data sebagai berikut:

\begin{tabular}{cccc}
\hline Skor & Jumlah Siswa & Presentase & Ketuntasan Belajar \\
\hline $0-74$ & 6 siswa & $20 \%$ & Belum Tuntas \\
$75-100$ & 24 siswa & $80 \%$ & Tuntas \\
& 30 siswa & 100 & \\
\hline
\end{tabular}

\section{Siklus 2}

Data yang diperoleh dalam aktivitas belajar siswa berdasaran siklus 1 antara lain :

\begin{tabular}{clc}
\hline NO & \multicolumn{1}{c}{ Jenis Kegiatan } & Jumlah \\
\hline 1 & Siswa mendengarkan dan memperhatikan guru & $3,5 \%$ \\
2 & Siswa membaca buku dan LKS & $3,4 \%$ \\
3 & Siswa mampu mengungkapkan pemikiran tentang materi yang diajarkan & $3,4 \%$ \\
4 & Siswa berdiskusi dalam kelompok belajar & $3,5 \%$ \\
5 & Siswa mengajukan dan menanggapi pertanyaan & $3,4 \%$ \\
6 & Siswa menghargai pendapat orang lain & $3,3 \%$ \\
7 & Siswa mempresentasikan hasil kerja kelompoknya di depan kelas & $3,6 \%$ \\
\hline
\end{tabular}

Berdasarkan data yang diperoleh dalam aktivitas belajar siswa dapat diperoleh kesimpulan bahwa siswa yang mendengarkan dan memperhatika guru sebanyak 3,5\%. Siswa yang membaca buku dan LKS sebanyak 3,4\%. Siswa mampu mengungkapkan pemikiran tentang materi yang diajarkan sebnayak $3,4 \%$. Siswa berdiskusi dalam kelompok belajar sebanyak 3,5\%. Siswa mengajukan dan menanggapi pertanyaan sebanyak 3,4\%. Siswa menghargai pendapat orang lain sebanyak 3,3\% dan siswa mempresentasikan hasil kerja kelompoknya di depan kelas sebanyak 3,6\%.

Berdasarkan data yang diperoleh pada siklus 2 pada aktivitas guru antara lain :

\begin{tabular}{clc}
\hline NO & \multicolumn{1}{c}{ Jenis Kegiatan } & Jumlah \\
\hline 1 & Guru memberi salam dan menyapa siswa & $3,5 \%$ \\
2 & Guru mengecek kehadiran siswa & $4 \%$ \\
3 & Guru memberi motivasi & $3 \%$ \\
4 & Guru menyampaikan tujuan pembelajaran & $4 \%$ \\
5 & Guru menyampaikan metode pembelajaran & $4 \%$ \\
6 & Guru menjelaskan materi pembelajaran & $3 \%$ \\
7 & Guru mengajukan pertanyaan & $3,5 \%$ \\
8 & Guru menginstrusikan siswa untuk berdiskusi & $4 \%$ \\
9 & Guru menginstruksikan siswa untuk bekerja sama & $3 \%$ \\
10 & Guru menugaskan siswa untuk memberi komentar & $3 \%$ \\
11 & Guru merefleksi tugas siswa & $3 \%$ \\
12 & Guru membimbing siswa untuk menarik kesimpulan & $3 \%$ \\
13 & Guru memberikan tugas untuk di rumah & $4 \%$ \\
\hline
\end{tabular}


Berdasarkan analisis data yang diperoleh didapat data guru memberi salam dan menyapa siswa sebanyak 3,5\%. Guru mengecek kehadiran siswa sebanyak 4\%. Guru memberi motivasi sebanyak 3\%. Guru menyampaikan tujuan pembelajaran sebanyak $4 \%$. Guru menyampaikan metode pembelajaran sebanyak $4 \%$. Guru menjelaskan materi pembelajaran sebanyak 3\%. Guru mengajukan pertanyaan sebanyak 3,5\%. Guru menginstrusikan siswa untuk berdiskusi sebanyak 4\%. Guru menginstruksikan siswa untuk bekerja sama sebanyak 3\%. Guru menugaskan siswa untuk memberi komentar sebanyak 3\%. Guru merefleksi tugas siswa sebanyak 3\%. Guru membimbing siswa untuk menarik kesimpulan sebanyak 3\% dan Guru memberikan tugas untuk di rumah sebanyak 4\%.

\section{Data Hasil Belajar Siswa Pada Siklus 2}

Data hasil belajar siswa pada siklus 2 pada materi pokok dinamika kependudukan di Indonesia diperoleh data sebagai berikut:

\begin{tabular}{cccc}
\hline Skor & Jumlah Siswa & Presentase & Ketuntasan Belajar \\
\hline $0-74$ & 3 siswa & $10 \%$ & Belum Tuntas \\
$75-100$ & 27 siswa & $90 \%$ & Tuntas \\
& 30 siswa & $100 \%$ & \\
\hline
\end{tabular}

\section{Pembahasan}

\section{Aktivitas belajar Siswa}

Berdasarkan hasil yang diperoleh pada penelitian di atas di antara kedua siklus dapat diperoleh data bahwa pada siklus 1 nilai rata-rata pada aktivitas belajar siswa di siklus 1 adalah 2,6 sedangkan nilai rata-rata pada siklus 2 diperoleh nilai sebesar 3,4. Hal ini menunjukkan terdapat peningkatan pada aktivitas belajar siswa.

\section{Aktivitas Guru}

Berdasarkan hasil yang diperoleh pada penelitian di atas di antara kedua siklus dapat diperoleh data bahwa pada siklus 1 nilai rata-rata pada aktivitas guru di siklus 1 adalah 3,4 sedangkan nilai rata-rata pada siklus 2 diperoleh nilai sebesar 3,5. Hal ini menunjukkan terdapat peningkatan pada aktivitas guru.

\section{Hasil Belajar Siswa}

Berdasarkan hasil yang dipeoleh pada penelitian di atas khususnya pada materi Dinamika Kependudukan di Indonesia terdapat hasil yang signifikan terhadap ketuntasan belajar siswa pada siklus 1 dan siklus 2 sebesar 10\%.

\section{SIMPULAN}

Berdasarkan data yang diperoleh dari penelitian di atas dapat disimpulkan :

1. Bedasarkan data yang diperoleh dalam aktivitas belajar siswa dalam siklus 1 didapat kesimpulan bahwa siswa yang mendengarkan dan memperhatika guru sebanyak 2,5\%. Siswa yang membaca buku dan LKS sebanyak 2,7\%. Siswa mampu mengungkapkan pemikiran tentang materi yang diajarkan sebnayak 2,7 \%. Siswa berdiskusi dalam kelompok belajar sebanyak 2,7\%. Siswa mengajukan dan menanggapi pertanyaan sebanyak 2,7 \%. Siswa menghargai pendapat orang lain sebanyak $2,5 \%$ dan siswa mempresentasikan hasil kerja kelompoknya di depan kelas sebanyak $2,6 \%$.

2. Analisis data guru pada siklus 1 didapat data guru memberi salam dan menyapa siswa sebanyak $3 \%$. Guru mengecek kehadiran siswa sebanyak 3\%. Guru memberi motivasi sebanyak 2\%. Guru menyampaikan tujuan pembelajaran sebanyak $3 \%$. Guru menyampaikan metode pembelajaran sebanyak 3,5\%. Guru menjelaskan materi pembelajaran sebanyak $3 \%$. Guru mengajukan pertanyaan sebanyak $2 \%$. Guru menginstrusikan siswa untuk berdiskusi sebanyak $3 \%$. Guru menginstruksikan siswa untuk bekerja sama sebanyak $2,5 \%$. Guru menugaskan siswa untuk memberi komentar sebanyak $2 \%$. Guru merefleksi tugas siswa sebanyak 2,5\%. Guru membimbing siswa untuk menarik kesimpulan sebanyak 2,5 \% dan Guru memberikan tugas untuk di rumah sebanyak 3\%.

3. Pada siklus 2 aktivitas belajar siswa dapat diperoleh kesimpulan bahwa siswa yang mendengarkan dan memperhatika guru sebanyak 3,5\%. Siswa yang membaca buku dan LKS sebanyak 3,4\%. Siswa mampu mengungkapkan pemikiran tentang materi yang diajarkan sebnayak 3,4 \%. Siswa berdiskusi dalam kelompok belajar sebanyak 3,5\%. Siswa mengajukan dan menanggapi pertanyaan sebanyak $3,4 \%$. Siswa menghargai pendapat orang lain sebanyak 3,3\% dan siswa mempresentasikan hasil kerja kelompoknya di depan kelas sebanyak $3,6 \%$.

4. Berdasarkan analisis data yang diperoleh pada siklus 2 didapat data guru memberi salam dan menyapa siswa sebanyak 3,5\%. Guru mengecek kehadiran siswa sebanyak 4\%. Guru memberi motivasi sebanyak 3\%. Guru menyampaikan tujuan pembelajaran sebanyak $4 \%$. Guru menyampaikan metode pembelajaran sebanyak $4 \%$. Guru 
menjelaskan materi pembelajaran sebanyak 3\%. Guru mengajukan pertanyaan sebanyak 3,5 \%. Guru menginstrusikan siswa untuk berdiskusi sebanyak 4\%. Guru menginstruksikan siswa untuk bekerja sama sebanyak 3\%. Guru menugaskan siswa untuk memberi komentar sebanyak 3\%. Guru merefleksi tugas siswa sebanyak $3 \%$. Guru membimbing siswa untuk menarik kesimpulan sebanyak 3\% dan Guru memberikan tugas untuk di rumah sebanyak $4 \%$.

\section{Saran}

1. Hendaknya sekolah-sekolah menginspirasi guru-guru secara umum melaksanakan penelitian tindakan kelas untuk mengatasi permasalahan- permasalahan yang dihadapi dalam pembelajaran di kelas. Karena penelitian tindakan kelas (classroom action research) membantu dalam meningkatkan mutu pembelajaran di sekolah.

2. Diharapkan guru menggunakan strategi pembelajaran inkuiri sebagai alternatif pendekatan dalam proses pembelajaran Geografi.

3. Diharapkan guru menggunakan strategi pembelajaran inkuiri untuk meningkatkan keterampilan guru dalam menyampaikan materi pembelajaran.

\section{DAFTAR PUSTAKA}

Indeks Sanjaya Wina. 2010. Strategi Pembelajaran Berorientasi Standar Proses Pendidikan. Jakarta: Kencana

Jacobsen A David, Eggen Paul, dan Kauchak Donal. 2009. Methods for Teaching, Terjemahan: Achmad Fawaid dan Khoirul Anam, Edisi kedelapan. Yogyakarta: Pustaka Pelajar

Mardapi Djemari. 2012. Pengukuran Penilaian dan Evaluasi Pendidikan. Yogyakarta: Nuha Medika

Martinis Yamin. 2005. Strategi Pembelajaran Berbasis Kompetensi. Jakarta: Gaung Persada Press

Mulyasa. (2006). Menjadi Guru Profesional Menciptakan Pembelajaran Kreatif dan Menyenangkan. Bandung: Penerbit PT Remaja Rosdakarya

Putra R Sitiatava. Desain Belajar Mengajar Kreatif Berbasis Sains. 2013. Jogyakarta. Diva Press

Samatowa Usman. 2010. Pembelajaran IPA di Sekolah Dasar. Jakarta. PT.

Sugiyono. 2011. Statistika untuk Penelitian. Bandung. CV Alfabeta.

Suharsimi Arikunto. 2013. Prosedur Penelitian Suatu Pendekatan Praktek.Jakarta: Rineka Cipta.

Suprijono Agus. 2013. Cooperative Learning, Teori dan Aplikasi PAIKEM. Jogyakarta: Pustaka Pelajar.

Susanto Ahmad. 2013. Teori Belajar dan Pembelajaran di Sekolah Dasar. Jakarta: PT Kharisma Putra Utama. 